\title{
KAJIAN PENGARUH VARIASI METAKAOLIN TERHADAP PARAMETER BETON MEMADAT MANDIRI MUTU TINGGI
}

\author{
Wibowo' ${ }^{1)}$ Endah Safitri'), dan Luth Fian Fatoni ${ }^{3)}$ \\ 1)2DDosen Program Studi Teknik Sipil, Fakultas Teknik, Universitas Sebelas Maret \\ ${ }^{3}$ Mahasiswa Dosen Program Studi Teknik Sipil, Fakultas Teknik, Universitas Sebelas Maret \\ J1. Ir. Sutami 36 A, Kentingan, Surakarta 57126, Telp (0271)647069, Fax 662118 \\ Email:Luthfian20@gmail.com
}

\begin{abstract}
High strength self-compacting concrete is a type of concrete that has a high compressive strength and is able to flow and fill the formwork without the help of vibrating tool in the compaction process and without bleeding or segregation. Metakaolin is pozzolan that got from basic material kaolin that go through dehidroksilation process result of heating at $650^{\circ} \mathrm{C}-900^{\circ} \mathrm{C}$ for 6 hours. The addition of metakaolin in the concrete mixture aims to increase the compressive strength of the concrete. Through the pozzolanic reaction of silica compound of metakaolin and $\mathrm{CH}$ compound from the hydration reaction yielded CSH compound which acts as an adhesive and filler. As the metakaolin volume increases, the workability of the concrete decreases and exceeds the standard of self-compacting concrete parameters. The parameter includes fillingabiliy, passingability, and segregation resistance. It is because the smaller metakaolin powder has a wider cross-sectional area compared to cement so it will increase the need of water to react and cause the concrete to be difficult to work. The result of the study showed that the concrete mixture with the use of metakaolin 12,5\% from cement weight and FAS 0,31 gives concrete with good SCC parameter although the mixture is still quite condensed because the silica in metakaolin produce sticky texture on the concrete.
\end{abstract}

Keywords: High strength concrete, metakaolin, water cement factor, SCC parameter, workability.

\section{Abstrak}

Beton mutu tinggi memadat mandiri merupakan jenis beton yang memiliki kuat tekan tinggi dan mampu mengalir mengisi bekisting tanpa perlu bantuan alat penggetar dalam proses pemadatannya serta tanpa terjadi bleeding ataupun segregasi. Metakaolin merupakan pozzolan yang diperoleh dari bahan dasar kaolin yang mengalami proses dehidroksilasi akibat pemanasan pada suhu $650^{\circ} \mathrm{C}-900^{\circ} \mathrm{C}$ selama 6 jam. Penambahan metakaolin dalam campuran beton bertujuan untuk meningkatkan kuat tekan beton. Melalui reaksi pozzolanik senyawa silika pada metakaolin dengan senyawa $\mathrm{CH}$ hasil reaksi hidrasi dihasilkan senyawa CSH yang berperan sebagai perekat sekaligus filler. Seiring dengan bertambahnya volume metakaolin yang digunakan menyebabkan workabilitas beton semakin menurun dan melampaui standar parameter beton memadat sendiri. Parameter tersebut diantaranya adalah fillingabiliy, passingability, dan segregation resistance. Hal tersebut disebabkan karena serbuk metakaolin yang berukuran lebih kecil dibandingkan dengan semen memiliki luas penampang yang lebih luas sehingga meningkatkan kebutuhan air untuk bereaksi dan menyebabkan beton menjadi sukar untuk dikerjakan. Hasil penelitian menunjukkan bahwa campuran beton dengan penggunaan metakaolin 12,5\% dari berat semen dan faktor air semen 0,31 mampu memberikan beton dengan parameter SCC yang cukup baik, meskipun campuran masih tergolong cukup kental dikarenakan silika pada metakaolin menghasilkan tekstur yang lengket pada beton.

Kata kunci: Beton mutu tinggi, metakaolin, faktor air semen (FAS), parameter SCC, workabilitas

\section{PENDAHULUAN}

Beton merupakan bahan yang umum digunakan dalam dunia konstruksi. Di Indonesia, beton masih menjadi bahan konstruksi yang digemari jika dibandingkan dengan bahan lain seperti baja dan kayu. Hal tersebut menjadikan inovasi-inovasi pada beton terus berkembang untuk meningkatkan kualitas dan mutu beton.

Beton mamadat mandiri atau self-compacting concrete (SCC) adalah beton yang dapat mengalir dan memenuhi tempatnya karena berat sendirinya dan mampu memadat dengan baik tanpa perlu menggunakan vibrator dan tidak menimbulkan efek samping berupa bleeding ataupun segregasi, sehingga menjadikan beton SCC sangat bermanfaat dalam dunia konstruksiBeton mutu tinggi memadat mandiri atau high strength self-compacting concrete (HSSCC) adalah inovasi beton yang memiliki standar kuat tekan tinggi. Beton HSSCC sangat dipengaruhi oleh material dan proporsi campuran beton. Maka dari itu, penting untuk memperhatikan mix design dari beton HSSCC agar hasil yang diperoleh dapat maksimal. 
Metakaolin merupakan pozzolan yang berasal dari bahan kaolin yang telah melalui proses pemanasan pada suhu $500^{\circ} \mathrm{C}-900^{\circ} \mathrm{C}$ dan berbentuk serbuk halus dengan ukuran 0,5 sampai 5 mikron. Metakaolin digunakan sebagai pengganti semen dimana senyawa silika yang terkandung didalamnya akan bereaksi dengan $\mathrm{CH}$ hasil reaksi hidrasi semen dan membentuk senawa CSH yang berperan sebagai perekat sekaligus filler sehingga mampu meningkatkan kuat tekan beton.

Dalam penelitian yang telah dilakukan sebelumnya oleh Dharmawan (2017), penambahan metakaolin menyebabkan beton semakin menjauhi parameter SCC, dimana parameter yang diamati adalah passingability, fillingability, dan segregation resistance. Maka dari itu, perlu dilakukan pengkajian yang lebih mendalam untuk mengetahui penyebab dari perubahan sifat yang dialami beton serta untuk menukur kadar maksimum untuk penambahan metakaolin pada beton.

Diperkirakan salah satu penyebab workabilitas beton semakin menjauhi parameter SCC dipengaruhi oleh faktor air yang digunakan dalam pembuatan beton matakaolin. Maka dari itu, perlu dikaji lebih mendalam terhadap variasi antara air yang digunakan dengan volume bubuk metakaolin yang ditambahkan dalam beton agar diperoleh beton yang memenuhi parameter-parameter SCC dengan kuat tekan yang tinggi.

\section{LANDASAN TEORI}

\section{Beton mutu tinggi memadat mandiri}

Menurut Standar Nasional Indonesia (SNI 03-2847-2002), beton adalah campuran antara semen Portland atau semen hidraulik lain, agregat halus, agregat kasar dan air dengan atau tanpa bahan tambahan yang membentuk massa padat. Keawetan, kekuataan, dan sifat beton lainnya juga dipengaruhi oleh sifat bahan dasar yang digunakan, perbandingan bahan-bahan penyusun beton, cara pencampuran ketika pembuatan, dan cara pemedatan serta perawatan selama proses pengerasan. Kemajuan teknologi beton juga menjadikan beton mampu memenuhi berbagai situasi yang ada dilapangan dan kemudahan dalam pengerjaannya.

Beton mutu tinggi (bigh strength concrete) yang tercantum dalam SNI 03-6468-2000 didefinisikan sebagai beton yang mempunyai kuat tekan yang disyaratkan lebih besar sama dengan 41,4 MPa. Upaya untuk mendapatkan beton mutu tinggi diantaranya dengan meningkatkan mutu material pembentuknya, misalnya kekerasan agregat dan kehalusan butir semen.

Beton memadat mandiri (self-compacting concrete (SCC)) adalah beton yang mampu mengalir sendiri yang dapat dicetak pada bekisting dengan tingkat penggunaan alat pemadat yang sangat sedikit atau bahkan tidak dipadatkan sama sekali. Beton ini akan mengalir mandiri mengisi semua ruang mengikuti prinsip gravitasi, termasuk pada pengecoran beton dengan tulangan pembesian yang sangat rapat. (Rusyandi, 2012). Metode Self Compacting Concrete (SCC) mempunyai tujuan mencapai workabilitas yang baik dan tidak terjadi segregasi pada beton.

\section{Metakaolin}

Metakaolin diperoleh dari bahan dasar kaolin yang dipanaskan pada suhu $650^{\circ} \mathrm{C}-900^{\circ} \mathrm{C}$ selama 6-7 jam sehingga kaolin tersebut mengalami proses dehidroksilasi. Proses tersebut memecah struktur kaolin sedemikian rupa sehingga lapisan alumina dan silika menjadi mengerut dan kehilangan keteraturannya dan terbentuklah metakaolin (Justice, 2005).

Metakaolin berperan sebagai pozzolan yang akan bereaksi dengan senyawa $\mathrm{CH}$ hasil reaksi hidrasi semen dan membentuk senyawa CSH yang berfungsi sebagai perekat sekaligus filler pada campuran beton sehingga dapat meningkatkan mutu dari beton itu sendiri. Berikut ini reaksi pozzolanik metakaolin:

$$
\begin{array}{rlrl}
2 \mathrm{C}_{3} \mathrm{~S}+11 \mathrm{H} & \rightarrow & \mathrm{C}_{3} \mathrm{~S}_{2} \mathrm{H}_{8}+3 \mathrm{CH} \\
& & (\mathrm{C}-\mathrm{S}-\mathrm{H}) \quad(\mathrm{CH}) \\
2 \mathrm{C}_{2} \mathrm{~S}+9 \mathrm{H} & \rightarrow & \mathrm{C}_{3} \mathrm{~S}_{2} \mathrm{H}_{8}+\mathrm{CH} \\
\mathrm{C}_{3} \mathrm{~A}+3 \mathrm{CSH}_{2}+26 \mathrm{H} & \rightarrow & \mathrm{C}_{6} \mathrm{AS}_{3} \mathrm{H}_{32} \\
\quad \text { (gypsum) } & & (\text { ettringite }) \\
2 \mathrm{C}_{3} \mathrm{~A}+\mathrm{C}_{6} \mathrm{AS}_{3} \mathrm{H}_{32}+4 \mathrm{H} \rightarrow & \rightarrow 3 \mathrm{C}_{4} \mathrm{ASH}_{12} \\
& & (\text { monosulfate })^{2} \\
\mathrm{C}_{4} \mathrm{ASH}_{12}+2 \mathrm{CSH}_{2} & \rightarrow & \mathrm{C}_{6} \mathrm{AS}_{3} \mathrm{H}_{32} \\
\mathrm{MK}\left[\mathrm{Al}_{2} \mathrm{Si}_{2} \mathrm{O}_{7}\right]+\mathrm{CH}+\mathrm{H} \rightarrow & \mathrm{C}-\mathrm{S}-\mathrm{H}, \mathrm{C}_{4} \mathrm{AH}_{13}, \mathrm{C}_{3} \mathrm{AH}_{6}, \mathrm{C}_{2} \mathrm{ASH}_{8}
\end{array}
$$




\section{Faktor air semen}

Faktor air semen (FAS) atau water content ratio (wcr) adalah indikator penting dalam perancangan campuran beton karena FAS merupakan perbandingan jumlah air terhadap jumlah semen dalam suatu campuran beton (Tjokrodimuljo, 1992), jadi dapat dikatakan,

$$
\text { FAS }=\frac{\text { Berat air }\left(\mathrm{kg} / \mathrm{m}^{3}\right)}{\text { Jumlah semen }\left(\mathrm{kg} / \mathrm{m}^{3}\right)}
$$

Faktor air semen juga sangat berhubungan dengan kuat tekan beton seperti yang dijelaskan oleh Murdock dan Brook (1986), bahwa pada beton dalam pengujian tertentu, jumlah air semen yang dipakai menentukan kuat tekan beton, asalkan campuran cukup mudah dikerjakan. Namun, nilai FAS yang semakin rendah tidak selalu berarti bahwa kekuatan beton semakin tinggi. Jika FAS semakin rendah, maka beton akan semakin sulit dipadatkan. Dengan demikian, ada suatu nilai FAS yang optimal yang dapat menghasilkan kuat tekan beton yang maksimal.

\section{Parameter SCC}

Pengujian parameter SCC dilakukan untuk menilai workabilitas dari campuran beton yang direncanakan. Workabilitas sendiri menunjukkan kemudahan dari suatu campuran beton untuk dikerjakan, mulai dari pembuatan campuran, penuangan beton dalam cetakan/bekisting, dan pemadatan sesuai dengan tujuan pekerjaannya tanpa terjadi perubahan yang menimbulkan kesukaran atau penurunan mutu.

Parameter SCC yang diamati diantaranya adalah sebagai berikut

\section{a. Fillingability}

Merupakan parameter yang menunjukkan kemampuan beton untuk mengalir dengan tetap mempertahankan homogenitasnya. Kemampuan beton mengalir ditunjukkan dengan diameter sebaran dan homogenitas beton segar yang dalam pengujian ini diindikasikan oleh kecepatan beton untuk mengalir.

b. Passingability

Merupakan parameter yang menunjukkan kemampuan pengaliran beton segar melewati komponen besi penghalang dimana berat beton segar yang berada dalam kotak vertikal memberikan daya dorong beton untuk melewati celah tulangan tersebut.

c. Segregation Resistance

Merupakan parameter yang menunjukkan kemampuan beton segar untuk memperthankan homogenitasnya setelah proses penuangan. Pengujian ini mengindikasikan apakan campuran mengalami segregasi atau tidak

\section{METODE PENELITIAN}

Penelitian dimulai dari persiapan material, pemeriksaan bahan, perencanaan rancang campur beton dan dilanjutkan dengan pembuatan benda uji serta pengujian benda uji, kemudian dari hasil yang diperoleh dilakukan analisis dan pembahasan sehingga dapat ditarik kesimpulan. Pemeriksaan pada material dilakukan untuk menguji kualitas dari material sehingga campuran beton yang dibuat dapat mencapai standard dan mutu yang telah ditetapkan. Perencanaan campuran benda uji dilakukan dengan cara trial hingga menemukan spesifikasi standar pengujian.

\section{Rancang campur beton}

Benda uji yang dibuat adalah beton memadat mandiri mutu tinggi (bigh strength self-compacting concrete - HSSCC) dengan variasi faktor air semen dan metakaolin. Rancang campur beton memadat mandiri mutu tinggi diperoleh dengan metode trial yang mengacu pada standar EFNARC 2002 untuk beton segar dan EFNARC 2005 untuk spesifikasi dari rancang campur beton yang direncanakan. Melalui hasil trial diperoleh rancang capur terbaik ang disajikan pada Tabel 1 
Tabel 1 Rancang campur beton HSSCC

\begin{tabular}{|c|c|c|c|c|c|c|c|}
\hline $\begin{array}{c}\text { Nama } \\
\text { Benda Uji }\end{array}$ & $\begin{array}{l}\text { FAS } \\
(\mathrm{w} / \mathrm{c})\end{array}$ & $\begin{array}{c}\mathrm{Air} \\
\left(\mathrm{lt} / \mathrm{m}^{3}\right)\end{array}$ & $\begin{array}{c}\text { Aggregat } \\
\text { Halus } \\
\left(\mathrm{kg} / \mathrm{m}^{3}\right)\end{array}$ & $\begin{array}{c}\text { Aggregat } \\
\text { Kasar } \\
\left(\mathrm{kg} / \mathrm{m}^{3}\right)\end{array}$ & $\begin{array}{c}\text { Semen } \\
\left(\mathrm{kg} / \mathrm{m}^{3}\right)\end{array}$ & $\begin{array}{c}\text { Metakao } \\
\operatorname{lin} \\
\left(\mathrm{kg} / \mathrm{m}^{3}\right)\end{array}$ & $\begin{array}{c}\text { Superplastic } \\
\text { izer } \\
\left(\mathrm{lt} / \mathrm{m}^{3}\right)\end{array}$ \\
\hline \multirow{3}{*}{ MK 0\% } & 0,27 & 162,00 & 921,13 & 765,98 & \multirow{3}{*}{600,00} & \multirow{3}{*}{0,00} & \multirow{3}{*}{10,20} \\
\hline & 0,29 & 174,00 & 903,79 & 751,57 & & & \\
\hline & 0,31 & 186,00 & 886,45 & 737,15 & & & \\
\hline \multirow{3}{*}{ MK $12,5 \%$} & 0,27 & 162,00 & 914,64 & 760,59 & \multirow{3}{*}{525,00} & \multirow{3}{*}{75,00} & \multirow{3}{*}{10,20} \\
\hline & 0,29 & 174,00 & 897,30 & 746,17 & & & \\
\hline & 0,31 & 186,00 & 879,96 & 731,75 & & & \\
\hline \multirow{3}{*}{ MK $17,5 \%$} & 0,27 & 162,00 & 912,04 & 758,43 & \multirow{3}{*}{495,00} & \multirow{3}{*}{105,00} & \multirow{3}{*}{10,20} \\
\hline & 0,29 & 174,00 & 894,70 & 744,01 & & & \\
\hline & 0,31 & 186,00 & 877,36 & 729,59 & & & \\
\hline \multirow{3}{*}{ MK 22,5\% } & 0,27 & 162,00 & 909,44 & 756,27 & \multirow{3}{*}{465,00} & \multirow{3}{*}{135,00} & \multirow{3}{*}{10,20} \\
\hline & 0,29 & 174,00 & 892,10 & 741,85 & & & \\
\hline & 0,31 & 186,00 & 874,77 & 727,43 & & & \\
\hline \multirow{3}{*}{ MK 27,5\% } & 0,27 & 162,00 & 906,85 & 754,11 & \multirow{3}{*}{435,00} & \multirow{3}{*}{165,00} & \multirow{3}{*}{10,20} \\
\hline & 0,29 & 174,00 & 889,51 & 739,69 & & & \\
\hline & 0,31 & 186,00 & 872,17 & 725,27 & & & \\
\hline
\end{tabular}

\section{Pengujian parameter SCC}

Pengujian beton segar dilakukan dengan 3 jenis pengujian yaitu Flow table test, L-box test, dan V-funnel test. Pengujian tersebut akan digunakan untuk menganalisis karakteristik dari beton HSSCC diantaranya fillingability, passingability, dan segregation resistance.

Standar yang digunakan dalam pengujian parameter SCC adalah standar dari The European Guidelines for SelfCompacting Concrete 2002 (EFNARC 2002). Metode dan standar yang digunakan disajikan dalam Tabel 2.

Tabel 2 Standar pengujian parameter SCC

\begin{tabular}{llccc}
\hline \multirow{2}{*}{ Metode } & \multirow{2}{*}{ Parameter } & \multirow{2}{*}{ Satuan } & \multicolumn{2}{c}{ Standar } \\
\cline { 4 - 5 } Slump-flow by Abrams cone & Fillingability & $\mathrm{Mm}$ & 650 & minimum \\
\hline$t_{500}$ Slump-flow & Fillingability & Detik & 2 & 500 \\
\hline$L$-box & Passingability & $\mathrm{h}_{1} / \mathrm{h}_{2}$ & 0,8 & 1 \\
\hline$V$-funnel & Fillingability & Detik & 6 & 12 \\
\hline$V$-funnel t 5 menit & Segregation Resistance & Detik & 0 & +3 \\
\hline
\end{tabular}

(sumber: EFNARC 2002)

\section{Pengujian kuat tekan beton}

Pengujian kuat tekan beton dilakukan menggunakan atat Compression Testing Macbine (CTM) ketika beton sudah mencapai usia 28 hari. Pengujian kuat tekan dilakukan untuk memastikan bahwa beton yang dihasilkan merupakan beton mutu tinggi, dimana beton mutu tinggi adalah beton yang memiliki kuat tekan lebih dari 41,4 MPa sesuai dengan standar SNI 03-6468-2000.

\section{HASIL DAN PEMBAHASAN}

\section{Hasil pengujian parameter SCC}

Bedasarkan pengujian yang telah dilaksanakan diperoleh hasil sebagai berikut

a. Flow table test

Berikut ini rekapitulasi hasil pengujian Flow table test disajikan pada Tabel 3 dan 4, kemudian perbandingan hasil pengujian Flow table test disajikan dalam bentuk grafik pada Gambar 1. 
Tabel 3 Rekapitulasi hasil pengujian $t_{500}$ Flow table

\begin{tabular}{ccccccc}
\hline \multirow{2}{*}{ Paramter } & \multirow{2}{*}{ FAS } & \multicolumn{5}{c}{ Metakaolin } \\
\cline { 2 - 6 } & & $0 \%$ & $12,5 \%$ & $17,5 \%$ & $22,5 \%$ & $27,5 \%$ \\
\hline \multirow{2}{*}{$\begin{array}{c}\boldsymbol{5}_{\mathbf{0} 00} \text { Slump-flow } \\
\text { (detik) }\end{array}$} & 0,27 & 4,73 & 8,53 & 16,75 & - & - \\
\cline { 2 - 6 } & 0,29 & 4,36 & 7,57 & 14,97 & - & - \\
\hline
\end{tabular}

Tabel 4 Rekapitulasi hasil pengujian diameter sebaran (d) Flow table

\begin{tabular}{ccccccc}
\hline \multirow{2}{*}{ Paramter } & \multirow{2}{*}{ FAS } & \multicolumn{5}{c}{ Metakaolin } \\
\cline { 2 - 6 } & & $0 \%$ & $12,5 \%$ & $17,5 \%$ & $22,5 \%$ & $27,5 \%$ \\
\hline $\begin{array}{c}\text { Slump-flow by } \\
\text { Abrams cone } \\
\text { (mm) }\end{array}$ & 0,27 & 696,67 & 550,00 & 490,00 & 402,50 & 347,50 \\
\cline { 2 - 6 } & 0,29 & 716,67 & 595,83 & 513,33 & 439,17 & 374,17 \\
\cline { 2 - 7 } & 0,31 & 794,17 & 650,83 & 540,00 & 467,50 & 395,00 \\
\hline
\end{tabular}

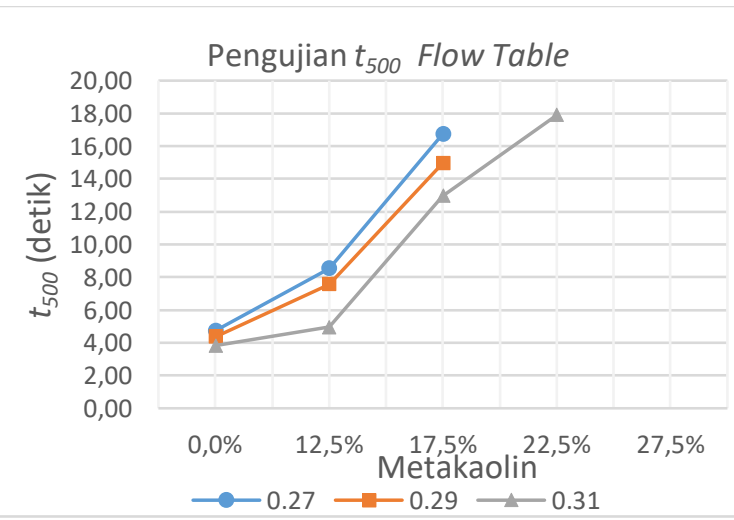

(a)

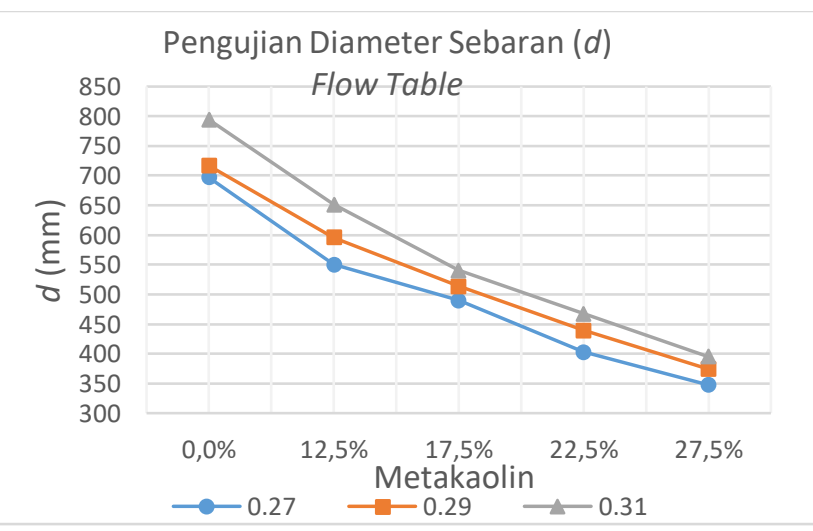

(b)

Gambar 1. Perbandingan hasil pengujian (a) $\mathrm{t}_{500}$ dan (b) diameter sebaran Flow table

\section{b. L-box test}

Berikut ini rekapitulasi hasil pengujian L-box test disajikan pada Tabel 5, kemudian perbandingan hasil pengujian L-box test disajikan dalam bentuk grafik pada Gambar 2.

Tabel 5 Rekapitulasi hasil pengujian $h_{1} / h_{2} L-b o x$

\begin{tabular}{ccccccc}
\hline \multirow{2}{*}{ Paramter } & \multirow{2}{*}{ FAS } & \multicolumn{5}{c}{ Metakaolin } \\
\cline { 2 - 6 } & & 0 & 12,5 & 17,5 & 22,5 & 27,5 \\
\hline L-box & 0,27 & 0,88 & 0,80 & 0,54 & 0,00 & 0,00 \\
$h_{1} / h_{2}$ & 0,29 & 0,92 & 0,85 & 0,61 & 0,12 & 0,00 \\
\cline { 2 - 6 } & 0,31 & 0,94 & 0,87 & 0,71 & 0,19 & 0,00 \\
\hline
\end{tabular}

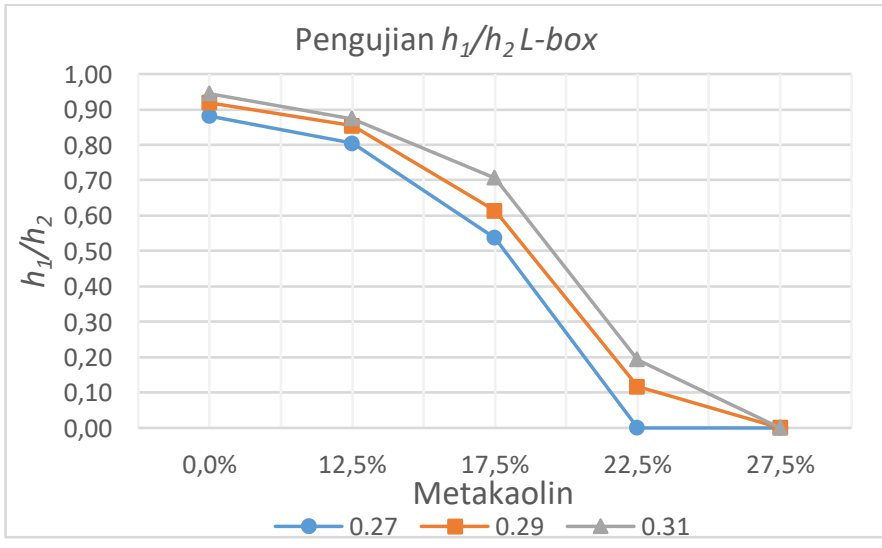

Gambar 2. Perbandingan hasil pengujian $h_{1} / h_{2} L-b o x$ 


\section{c. $V$-funnel test}

Berikut ini rekapitulasi hasil pengujian $V$-funnel test disajikan pada Tabel 6 dan 7, kemudian perbandingan hasil pengujian $V$-funnel dan $V$-funnel $t_{5}$ menit disajikan dalam bentuk grafik pada Gambar 3.

Tabel 6 Rekapitulasi hasil pengujian $V$-funnel

\begin{tabular}{ccccccc}
\hline \multirow{2}{*}{ Paramter } & \multirow{2}{*}{ FAS } & \multicolumn{5}{c}{ Metakaolin } \\
\cline { 2 - 7 } & & $0 \%$ & $12,5 \%$ & $17,5 \%$ & $22,5 \%$ & $27,5 \%$ \\
\hline \multirow{2}{*}{$\begin{array}{c}\text { V-Funnel } \\
\text { (detik) }\end{array}$} & 0,27 & 12,31 & 37,94 & 53,88 & - & - \\
\cline { 2 - 7 } & 0,29 & 11,11 & 33,89 & 43,13 & 88,54 & - \\
\cline { 2 - 7 } & 0,31 & 9,87 & 24,76 & 38,58 & 77,62 & - \\
\hline
\end{tabular}

Tabel 7 Rekapitulasi hasil pengujian $V$-funnel $t_{5}$ menit

\begin{tabular}{ccccccc}
\hline \multirow{2}{*}{ Paramter } & \multirow{2}{*}{ FAS } & \multicolumn{5}{c}{ Metakaolin } \\
\cline { 3 - 7 } & & $0 \%$ & $12,5 \%$ & $17,5 \%$ & $22,5 \%$ & $27,5 \%$ \\
\hline$V$-Funnel & 0,27 & 15,25 & 40,57 & 59,48 & - & - \\
\cline { 2 - 7 }$t_{5}$ menit & 0,29 & 13,34 & 36,72 & 51,68 & - & - \\
(detik) & 0,31 & 28,76 & 26,60 & 44,54 & - & - \\
\hline
\end{tabular}

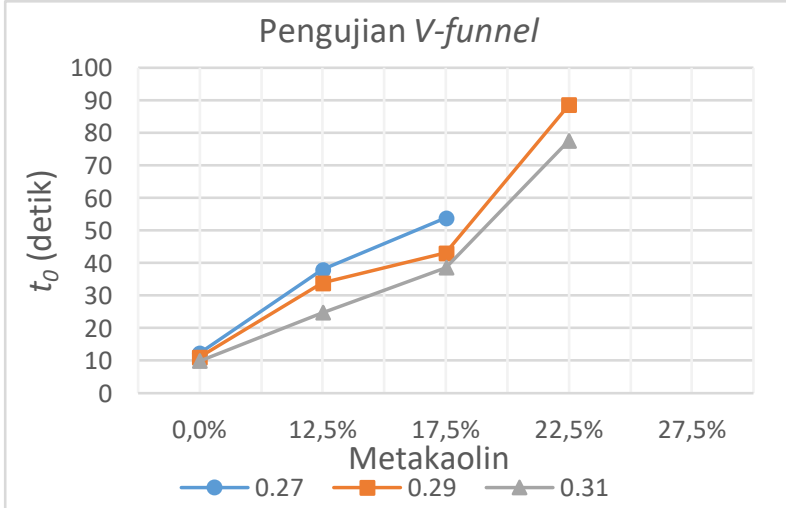

( a)

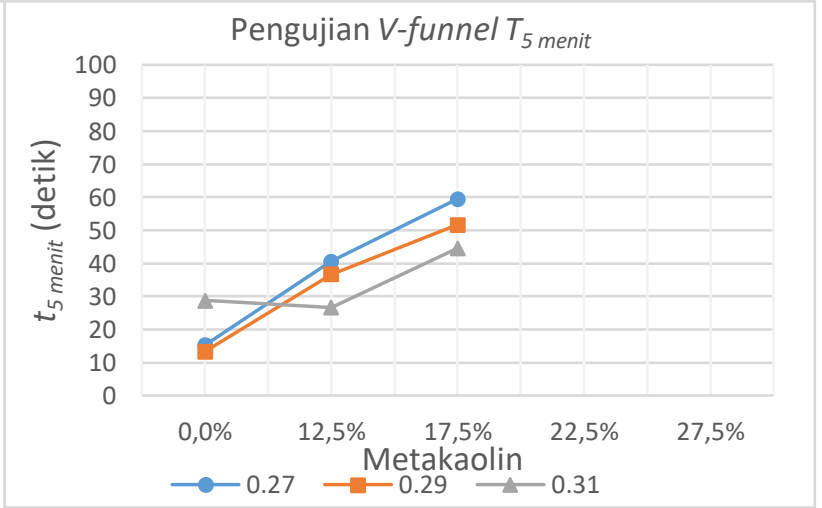

(b)

Gambar 3. Perbandingan hasil pengujian (a) V-funnel dan (b) V-funnel t5 menit

\section{Perubahan workabilitas}

Workabilitas beton memadat mandiri sangat dipengaruhi oleh rancang campur beton yang dibuat. Dari hasil pengujian benda uji MK 0\% (beton kontrol) dapat dikatakan bahwa rancang campur yang dibuat sudah layak dijadikan sebagai acuan, meskipun pada pengujian $V$-funnel MK $0 \%(0,27)$ belum memenuhi standar dan $V$ funnel $t_{5}$ menit $\mathrm{MK} 0 \%(0,31)$ terjadi segregasi. Berikut ini pembahasan mengenai perubahan masing-masing parameter SCC berdasarkan hasil pengujian yang telah dilakukan.

\section{a. Fillingability}

Parameter fillingability diperoleh dengan melakukan pengujian flow table dan $V$-funnel. Pada penelitian yang dilakukan diperoleh hasil yang menunjukkan bahwa penambahan metakaolin menurunkan kemampuan beton segar untuk dapat mengalir karena viskositas campuran yang meningkat seiring dengan bertambahnyya jumlah metakaolin sebegai pengganti semen. Ketiga variasi FAS yang digunakan memberikan hasil yang sama untuk setiap variasi metakaolin dimana untuk nilai FAS yang lebih tinggi memberikan kemampuan beton untuk mengalir yang lebih baik.

\section{b. Passingability}

Parameter passingability diperoleh dengan melakukan pengujian L-Box. Berdasarkan pengujian MK 0\% (beton kontrol) menunjukkan bahwa rancang campur yang dibuat tidak memiliki masalah pada penggunaan material, karena tidak menutup kemungkinan ukuran aggregat dan volume mortar yang terkandung dapat mempengaruhi kemampuan beton untuk mengalir melewati celah tulangan. Ukuran aggregat yang terlalu besar dapat menyebabkan aggregat menumpuk pada celah tulangan sehingga beton tidak dapat mengalir, begitu pula kemungkinan yang dapat terjadi apabila volume mortar terlalu sedikit. Kemudian pengaruh 
penggunaan metakaolin menyebabkan passingability beton semakin berkurang seiring dengan persentase penggunaan metakaolin yang digunakan sebagai pengganti semen.

\section{c. Segregation resistance}

Parameter segregation resistance diperoleh dengan melakukan pengujian $V$-funnel t5 menit Hasil pengujian yang dilakukan menunjukkan MK 0\% dengan FAS 0,31 mengalami segregasi yang ditunjukkan oleh selisih antara waktu $V$-funnel dengan $V$ funnel $t_{5}$ menit yang jauh. Terjadinya segregasi menyebabkan naiknya pasta semen keatas campuran beton segar sehingga aggregat kasar memenuhi celah $V$-funnel dan menyebabkan waktu pengeliran beton segar menjadi lebih lama.

Penggunaan metakaolin sebagai pengganti semen meningkatkan viskositas campuran sehingga lebih mampu untuk mempertahankan homogenitasnya. Hal tersebut dilihat dari benda uji MK 12,5\% dengan FAS 0,31 dimana campuran memiliki kekentalan yang lebih tinggi dan tidak terjadi segregasi. Namun, MK $12,5 \%$ tetam dinilai tidak memenuhi persyaratan karena hasil uji V-funnel yang tidak sesuai dengan standar yang digunakan.

\section{Kuat tekan beton}

Hasil pengujian kuat tekan akan disajikan dalam Tabel 8

Tabel 8 Rekapitulasi hasil pengujian kuat tekan

\begin{tabular}{ccccccc}
\hline \multirow{2}{*}{ Pengujian } & \multirow{2}{*}{ FAS } & \multicolumn{5}{c}{ Metakaolin } \\
\cline { 2 - 6 } & & $0 \%$ & $12,5 \%$ & $17,5 \%$ & $22,5 \%$ & $27,5 \%$ \\
\hline \multirow{2}{*}{$\begin{array}{c}\text { Kuat tekan } \\
(\mathrm{MPa})\end{array}$} & 0,27 & 47,66 & 68,9 & 71,33 & 54,8 & 49,68 \\
\cline { 2 - 6 } & 0,29 & 44,36 & 62,13 & 64,68 & 53,92 & 46,14 \\
\cline { 2 - 6 } & 0,31 & 43,5 & 54,14 & 59,66 & 51,41 & 45,03 \\
\hline
\end{tabular}

Hasil pengujian menunjukkan bahwa beton yang dibuat sesuai dangan standar SNI 03-6468-2000 sebagai beton mutu tinggi (f'c $>41,4 \mathrm{MPa})$

\section{KESIMPULAN}

Dari data hasil pengujan dan analisis yang telah dilakukan dapat ditarik kesimpulan sebagai berikut:

1. Penggunaan metakaolin sebagai pengganti semen menghasilkan beton dengan kekentalan yang semakin tinggi seiring dengan volume bubuk metakaolin yang digunakan. Hal tersebut menyebabkan campuran beton memadat mandiri semakin menjauhi standar passingability dan fillingability yang ditetapkan oleh EFNARC 2002, meskipun kekentalan campuran yang semakin tinggi menurunkan kecenderungan terjadinya segregasi (segregation resistance).

2. Penggunaan nilai faktor air semen yang lebih tinggi dengan berat semen yang sama akan menghasilkan campuran beton yang lebih encer. Namun nilai faktor air semen yang terlalu tinggi dapat menyebabkan beton mengalami segregasi. Seperti yang terjadi pada MK 0\% (FAS 0,31).

3. Campuran beton dengan FAS 0,31 dan metakaolin 12,5\% dapat memenuhi standar flow table dan L-Box, namun belum mampu memenuhi standar untuk $V$-funnel. Sedangkan untuk campuran beton dengan FAS $\leq 0,29$ dengan persentase metakaolin 22,5\% atau lebih tinggi menghasilkan campuran yang sangat kental sehingga tidak mampu untuk diuji parameter SCC.

\section{SARAN}

Saran yang dapat diberikan berdasarkan penelitian yang telah dilaksanakan antara lain.

1. Pembuatan rancang campur yang tepat perlu diperhatikan (ukuran aggregat, komposisi aggregat, faktor air semen, dan admixture yang digunakan) untuk menghasilkan beton yang memenuhi standar pengujian parameter SCC dan untuk mencapai kuat tekan yang tinggi.

2. Untuk menghasilkan beton yang lebih encer dapat dilakukan dengan menambah volume air yang digunakan atau dengan penambahan admixture dengan komposisi yang tepat. Perlu diperhatikan pula penambahan penggunaan air dapat menyebabkan penurunan kuat tekan beton.

3. Metode pembuatan benda uji, perawatan benda uji, serta proses-proses lain juga mempengaruhi hasil pengujian yang dilakukan, sehingga penelitian perlu memastikan bahwa kondisi ketika pembuatan dan perlakuan terhadap benda uji relatif sama.

4. Perlu dilakukan penelitian lebih lanjut untuk menghasilkan beton dengan bahan tambahan metakaolin yang memenuhi standar beton memadat mandiri dengan kuat tekan yang paling optimal. 


\section{DAFTAR PUSTAKA}

Badan Standarisasi Nasional. 2000. Standar Nasional Indonesia (SNI) 03 - 6468 - 2000 (Tata Cara Perencanaan Campuran Tinggi dengan Semen Portland Dengan Abu Terbang).

Badan Standarisasi Nasional. 2002. Standar Nasional Indonesia (SNI) 03 - 2847 - 2002 (Tata Cara Perbitungan Struktur Beton Untuk Bangunan).

Dharmawan, Emir A. 2017. "Kajian Pengarub Variasi Koposisi Metakaolin terhadap Parameter Beton Memadat Mandiri dan Kuat Tekan Beton Mutu Tinggi" Program Studi Teknik Sipil Fakultas Teknik Universitas Sebelas Maret

EFNARC. 2002. "Specification and Guidelines for Self-Compacting Concrete".

EFNARC. 2005. "Specification, Production, and Use".

Justice, J.M. 2005. "Evaluation of Metakaolins for Use as Supplementary Cementitious Materials". Thesis, Georgia Institute of Technology.

Murdock, L.J. Brook, K.M. 1986. “Bahan dan Praktek Beton”. Terjemahan Ir. Stephanus Hindarko. Jakarta: Erlangga.

Rusyandi, K., Mukodas, J., dan Gunawan, Y. 2012. "Perancangan Beton Self Compacting Concrete (Beton Memadat Sendiri) Dengan Penambahan Fly Ash dan Structuro." Jurnal Konstruksi Vol.10 No.01.

Tjokromuljo, Kardiyono. 1992. "Teknologi Beton". Yogyakarta; Biro Penerbit Teknil Sipil Universitas Gajah Mada. 